\title{
Fermentation Rates and Ethanol Accumulation in Relation to Flooding Tolerance in Rhizomes of
}

\section{Monocotyledonous Species}

\author{
L. S. MONK ${ }^{1}, R \cdot M \cdot M \cdot C R A W F O R D^{1,3}$ AND R. BR R NDLE \\ ${ }^{1}$ Department of Botany, The University, St Andrews, Scotland, U.K. \\ ${ }^{2}$ Institute of Plant Physiology, University of Berne, Switzerland
}

Received 22 July 1983

\begin{abstract}
Fermentation capacity as measured by alcohol dehydrogenase $(A D H)$ and lactate dehydrogenase $(L D H)$ activity were estimated together with ethanol and lactate accumulation over a period of $15 \mathrm{~d}$ anoxia in rhizomes of six monocotyledonous species. With the exception of Iris germanica all the species were characteristic wetland plants.

Under anoxia an accumulation of ethanol took place in all species. Lactic fermentation was found to be of less importance in every case. The amount of ethanol accumulated depended on the ability of the rhizome to eliminate it from its tissues. Despite great variations in fermentative capacity as seen in the $A D H$ measurements the wetland species did not accumulate ethanol to concentrations greater than $30 \mu \mathrm{mol} \mathrm{g}^{-1}$ fresh weight. This represented a plateau above which the ethanol concentration did not rise even with continued anaerobic incubation. No such plateau of ethanol accumulation was found in the dryland species Iris germanica which accumulated ethanol steadily reaching concentrations of $70 \mu \mathrm{mol}$ $\mathrm{g}^{-1}$ fresh weight.

If ethanol is toxic to higher plant tissues then the steady state condition of low ethanol accumulation found in wetland species will minimize this danger.
\end{abstract}

Key words: Ethanol; Flooding; Rhizomes.

\section{INTRODUCTION}

Stalkless flooded rhizomes of wetland plants are able to endure prolonged periods of oxygen deficiency until new growth re-establishes an oxygen transport path from shoot to root (Armstrong, 1979; Haldemann and Brändle, 1983). During this period the energy metabolism of the plant is altered (Pradet and Bomsel, 1978; Steinmann and Brändle, 1981) with the replacement of respiration by fermentation. Under controlled experimental conditions rhizomes of a number of wetland species have been shown to endure strict anoxia for one to two months (Crawford, 1982).

There is conflicting evidence as to whether the metabolism of such anoxia-tolerant wetland species differs from that of intolerant dryland plants. A comparison of $A D H$ activity in a number of flood-tolerant and intolerant species that had been kept inundated for a month led to the suggestion that low $A D H$ activities were associated with flood-tolerant species (Crawford, 1967). In some species such as maize (Marshall, Broué and Pryor, 1973), soft

\footnotetext{
${ }^{3}$ To whom correspondence should be sent.
} 
brome grass (Brown, Marshall and Munday, 1976), subterranean clover (Francis, Devitt and Steele, 1974) and sunflower (Torres and Diedenhofen, 1981) flood intolerant races can be distinguished from less susceptible races by the induction in the former of a highly active $A D H$ isoenzyme. The relationship between flooding tolerance and $A D H$ activity is, however, complicated by the fact that $A D H$ activity is not directly related to the degree of oxygen deficiency. Although $A D H$ induction commonly takes place under conditions of low oxygen supply, the extent of the response is reduced as conditions become progressively more anoxic (Wignarajah and Greenway, 1976).

Further research in which particular attention has been paid to estimating maximum possible $A D H$ activity has shown that it is not possible to make any universal generalization between maximum enzymatic activity and flooding tolerance (Smith and ap Rees, 1979). In addition a number of flood-tolerant plants such as rice and barnyard grass have relatively high glycolytic rates when inundated as growing seedlings (Rumpho and Kennedy, 1981). If flooding tolerance is associated in any way with ethanol accumulation as suggested in earlier studies (Crawford, 1967) then it is necessary to equate production rate with diffusive loss. Metabolic studies which concentrate on fermentative capacity alone do not take into account the great variation that exists in plant tissues in their ability to rid themselves of ethanol. Thus a low metabolic rate under conditions of oxygen deficiency may play an important role in the flooding tolerance of races and species where accumulation of metabolites cannot be avoided as in large non-porous rhizomes and in the early stages of seed germination before the rupture of the testa. However, a low metabolic rate under anoxia will not be of importance to flooding tolerance where ethanol is readily eliminated from plant tissues, provided that carbohydrate supplies are sufficient for prolonged fermentation.

The important criterion as regards tolerance of anoxia and the dangers of toxicity will be the amount of ethanol that accumulates in the rhizomes. If as reported earlier for Schoenoplectus lacustris (Duss and Brändle, 1982) wetland plants can eliminate ethanol directly from their rhizomes, then only a small accumulation may result, despite relatively high rates of fermentation. The following investigation was carried out on a group of monocotyledonous wetland plants and one dryland species to ascertain whether low accumulations of ethanol are generally associated with flooding tolerance.

\section{MATERIALS AND METHODS}

Plants of all species were collected locally (Berne-Switzerland) and grown until needed for experimentation in a glasshouse where the ambient temperature was kept between $14^{\circ} \mathrm{C}$ and $20^{\circ} \mathrm{C}$. The wetland species were Acorus calamus L., Iris pseudacorus L., Phragmites australis Trin. ex Steud., Schoenoplectus lacustris (L.) Palla and Typha latifolia L. All plants were investigated during the winter months, between October and March, when metabolism is sustained at a more or less steady level, in contrast to marked seasonal changes during the rest of the year (Steinmann and Brändle, in preparation). Rhizomes were pretreated and incubated anaerobically in the dark as described earlier by Monk and Brändle (1982). The anaerobic incubation lasted $15 \mathrm{~d}$ with $16 \mathrm{~d}$ for the aerobic controls and $8 \mathrm{~d}$ anoxia followed by $9 \mathrm{~d}$ air in the rhizomes studied for the recovery of aerobic metabolism.

At specific intervals rhizomes were removed from the appropriate treatments and the rate of oxygen uptake was determined according to Haldemann and Brändle (1983). Rhizomes for the determination of $A D H$ and $L D H$ were removed simultaneously, treatec as described earlier (Monk and Brändle. 1982), and enzymatic activity measured photometrically at $25^{\circ} \mathrm{C}$. In the present set of experiments, the final step in the preparation involved passing the extract through a Sephadex G 25 column and the protein content of the subsequent extract assayed by the Coomassie Blue method (Bio-Rad, Richmond, California, U.S.A.) and used as the basis for the calculation of enzymatic activity. Ethanol and lactate concentrations in the rhizome tissues were determined enzymatically (Bergmeyer, 1963) with test kits (Boehringer, Mannheim, W. Germany). Preparation of the extracts for the determination of ethanol, lactate and sugars was carried out at $0-4{ }^{\circ} \mathrm{C}$ as follows: rhizomes were homogenized in $6 \%$ perchloric acid and thus deproteinized, then centrifuged at $3500 \times g$ and subsequently neutralized with 
$5.0 \mathrm{M} \mathrm{K}_{2} \mathrm{CO}_{3}$. The concentrations of various sugars present were determined from the same extract. Total reducing sugars were measured colorimetrically according to Somogyi (1952). Glucose, fructose and sucrose were determined enzymatically after Bergmeyer (1963) using test kits as above.

\section{RESULTS AND DISCUSSION}

Rhizomes of all species showed depressed rates of $\mathrm{O}_{2}$ uptake when removed from anoxia (Fig. 1). The dryland species, $I$. germanica, possessed the lowest rate of $\mathrm{O}_{2}$ consumption of less than $20 \mu \mathrm{g} \mathrm{O}_{2} \mathrm{~g}^{-1}$ fr. wt. $\mathrm{h}^{-1}$. Nevertheless, when rhizomes were removed from $\mathrm{N}_{2}$ and further incubated in air, all species showed an increase in $\mathrm{O}_{2}$ uptake approaching that found

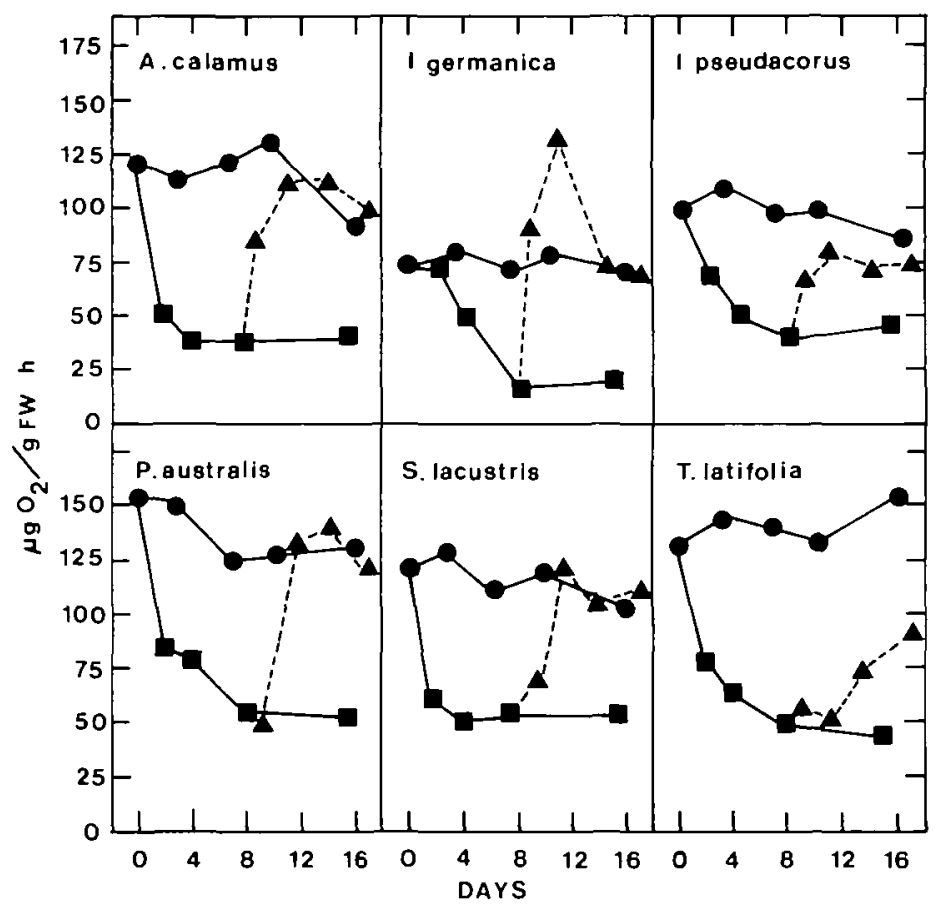

FIG. 1. $\mathrm{O}_{2}$ uptake of rhizomes, at $25^{\circ} \mathrm{C}$ under air $(-)$ ), during further incubation in air subsequent to anoxia $(---)$, and under $\mathrm{N}_{2}\left(\mathrm{a}_{-}\right)$. For $\mathrm{O}_{2}$ uptake of rhizomes from the anoxic treatment the rhizomes were removed from $\mathrm{N}_{2}$ and measured in air. Mean values from 2-4 rhizomes.

in the controls. Thus, it may be surmized that no irreparable damage at the ultrastructural level (Vartapetian, Andreeva, Kozlova and Agapova, 1977) had taken place during the period of $8 \mathrm{~d}$ without $\mathrm{O}_{2}$.

1. germanica $\mathrm{O}_{2}$ consumption was seen to overshoot the rate found in the controls by $100 \%$, when rhizomes from the anoxic treatment were re-introduced to air. This $\mathrm{O}_{2}$ consumption may, however, derive from non-respiratory as well as respiratory processes. Hunter, Hetherington and Crawford (1983) reported a significant increase in the lipid peroxidation product, malondialdehyde, in $I$. germanica, after $6 \mathrm{~h}$ re-exposure to air, subsequent to an anoxic treatment, while no increase was found in the related wetland species I. pseudacorus. It is possible that lipid peroxidation on re-exposure to air is a significant factor in the lethality of anoxia to I. germanica.

Alcoholic fermentation was found to operate on different levels in the various species (Fig. 2). In $A$. calamus rhizomes a relatively high $A D H$ activity of between $500-600 \mathrm{nM} \mathrm{mg}-1$ 


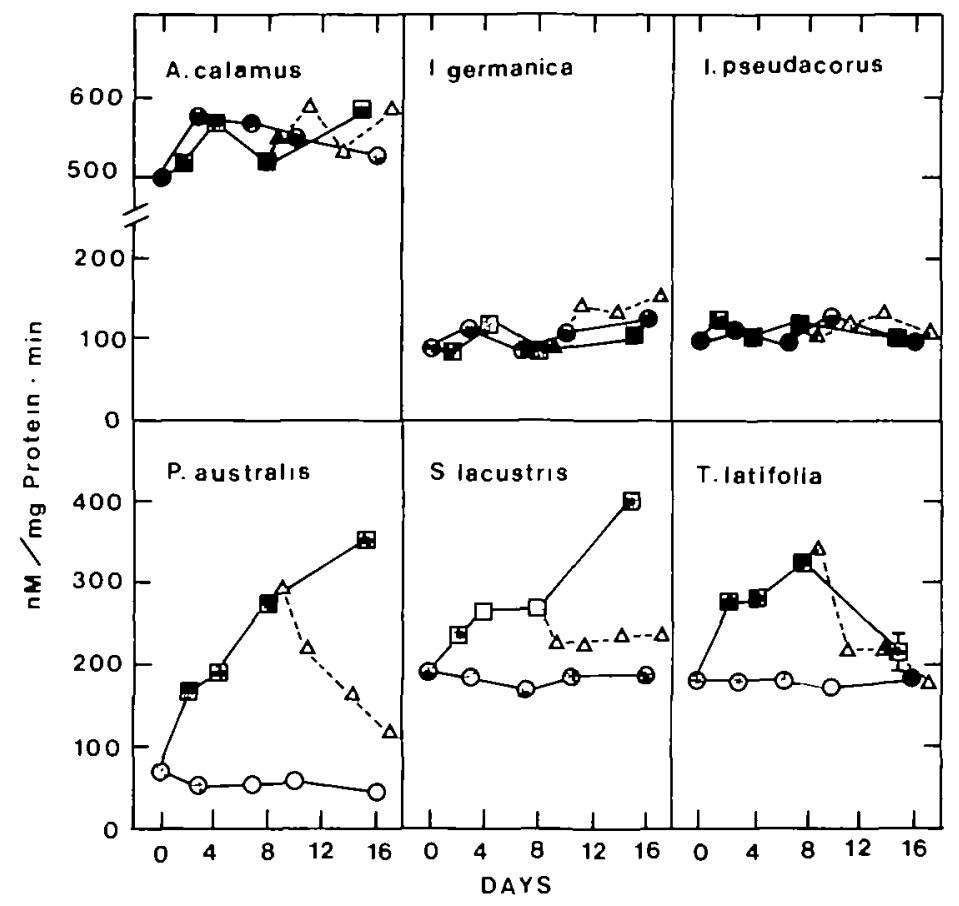

FIG. 2. $A D H$ activity of rhizomes under air $(\Theta-\Theta)$, under $\mathrm{N}_{2}(\Theta-\mathbb{Q})$, and during further incubation in air subsequent to anoxia $(\Delta----\Delta)$. Mean values from $2-5$ rhizomes.

protein $\min ^{-1}$ occurred under all treatments, with no induction of the enzyme detected. In comparison, I. germanica and I. pseudacorus both showed considerably lower activities in the region of $100 \mathrm{nM} \mathrm{mg}^{-1}$ protein $\mathrm{min}^{-1}$ under all treatments, again with no detectable induction. Phragmites australis and Schoenoplectus lacustris, on the other hand, exhibited an induction of $A D H$ under anoxia, where activity increased during the whole course of the treatment. Rhizomes of Typha latifolia showed an increase of $100 \%$ by the eighth day of anoxia, after which a decrease in activity, to a level comparable to that of the aerobic controls was observed.

If the accumulation of potentially toxic ethanol is avoided as shown by Bertani, Brambilla and Menegus (1980) in rice seedlings when $98 \%$ of ethanol produced was eliminated from the tissue into the medium, then an active alcoholic fermentation can be of advantage in maintaining a viable energy charge in the tissue (Pradet and Bomsel, 1978; Monk and Brändle, 1982). In the wetland plants investigated, the morphology of the rhizomes suggests that, at least in some cases, ethanol can be eliminated from the rhizome tissue with relative ease (Duss and Brändle, 1982). Ethanol, produced by the adventitious root system characteristic of monocotyledons, is probably also easily liberated due to the large surface area of the roots and the presence of aerenchyma (Armstrong, 1979).

Compared to alcoholic fermentation, lactic fermentation was found to operate at a lower level under nitrogen and air in all species (Table 1). In Schoenoplectus lacustris there was a 6-fold increase in $L D H$ activity in the absence of oxygen, but even this level lies well below the observed level of $A D H$ activity under nitrogen. Lactic fermentation then, seems to be limited to a certain level of activity. This is perhaps due to a regulation of a pH stat in the cell (Davies, Grego and Kenworthy, 1974). Thus, it appears that ethanol is the more favoured end-product of glycolysis. 
T A B LE 1. LDH activity and concentrations of lactate in the rhizomes after periods of 15/16 din $N_{2} /$ air

Mean values from 6-12 rhizomes \pm s.d.

\begin{tabular}{|c|c|c|c|c|}
\hline \multirow[t]{2}{*}{ Species } & \multicolumn{2}{|l|}{ Air } & \multicolumn{2}{|l|}{$\mathrm{N}_{2}$} \\
\hline & $\begin{array}{l}\mathrm{LDH} \\
\left(\mathrm{nM} \mathrm{mg} \mathrm{mg}^{-1} \text { Protein }\right. \\
\left.\mathrm{min}^{-1}\right)\end{array}$ & $\begin{array}{l}\text { Lactate } \\
\left(\mu \mathbf{M ~ g}^{-1} \text { fr. wt.) }\right.\end{array}$ & $\begin{array}{l}\mathrm{LDH} \\
\left(\mathrm{nM} \mathrm{mg}^{-1} \text { Protein }\right. \\
\left.\mathrm{min}^{-1}\right)\end{array}$ & $\begin{array}{l}\text { Lactate } \\
\left(\mu \mathrm{M} \mathrm{g}^{-1} \text { fr. wt. }\right)\end{array}$ \\
\hline A. calamus & $9 \cdot 5 \pm 2 \cdot 8$ & $<1$ & $18 \cdot 3 \pm 4 \cdot 0$ & $1.6 \pm 0.5$ \\
\hline 1. germanica & $4.4 \pm 1.8$ & $1.1 \pm 0.7$ & $6.5 \pm 2.2$ & $5.2 \pm 0.7$ \\
\hline I. pseudacorus & $6.9 \pm 2.5$ & $<1$ & $5 \cdot 7 \pm 1.4$ & $<1$ \\
\hline P. australis & $17 \cdot 5 \pm 2 \cdot 6$ & $<1$ & $28.4 \pm 7.8$ & $2.4 \pm 0.6$ \\
\hline S. lacustris & $9 \cdot 6 \pm 4 \cdot 3$ & $2.0 \pm 0.6$ & $54.5 \pm 2.6$ & $5 \cdot 3 \pm 0.7$ \\
\hline$T$. latifolia & $8 \cdot 7 \pm 2 \cdot 5$ & $2.4 \pm 0.8$ & $13 \cdot 4 \pm 2 \cdot 3$ & $4.2 \pm 0.7$ \\
\hline
\end{tabular}

Accumulation of ethanol, rather than total production, was determined in the various species (Fig. 3). It was of interest in this investigation to compare accumulation of ethanol in the rhizome tissue of the species chosen, in relation to tolerance of anoxia. In $A$. calamus, $I$. germanica and $I$. pseudacorus $A D H$ activity was not found to be correlated with ethanol accumulation. In $A$. calamus rhizomes concentrations of no more than $6.0 \mu \mathrm{M} \mathrm{g}^{-1} \mathrm{fr}$. wt. ethanol were observed during anaerobiosis, this amount being accumulated by day 4 and thereafter not exceeded. Although possessing the highest $A D H$ activity of the six species, $A$. calamus exhibited the lowest accumulation of ethanol, indicating that the plant is best able to eliminate the product into the surrounding gaseous or aqueous phase. Internal air spaces may account for up to $36 \%$ of the volume of the rhizome, and there is no cork layer to the epidermis, so that escape of ethanol may proceed readily.

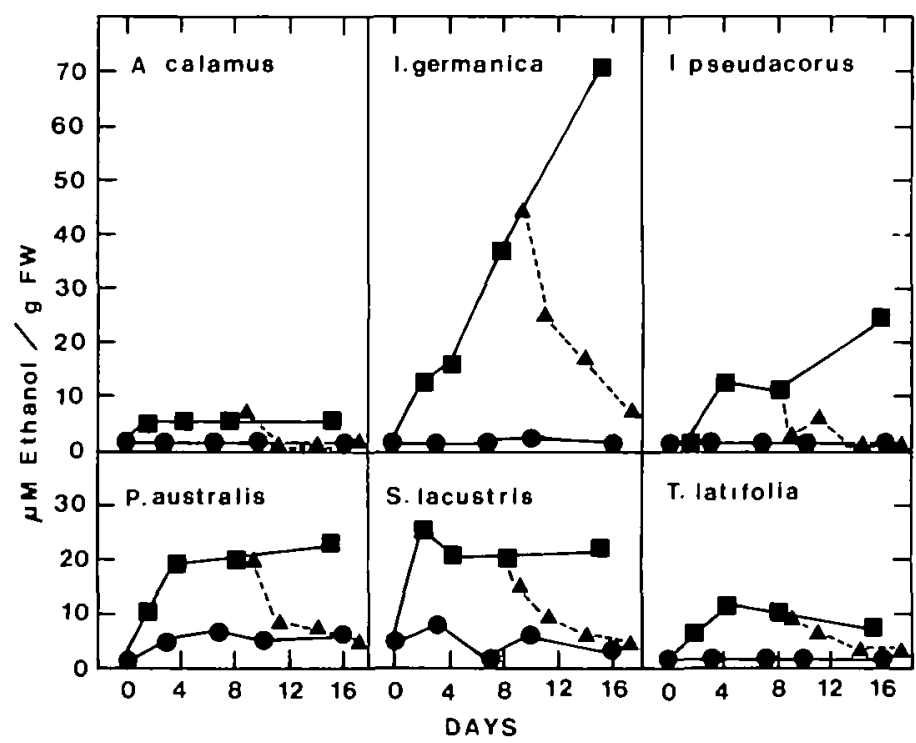

FIG. 3. Ethanol accumulation in the rhizome tissue under air $\left(\mathrm{O}_{-}^{-}\right)$, under $\mathrm{N}_{2}(\mathbf{C}-\mathbf{a}$ ), and during further incubation in air subsequent to anoxia ( $\mathbf{-}---\mathbf{A})$. Mean values from $2-4$ rhizomes. 
In $P$. australis an accumulation of approximately $20 \mu \mathrm{M} \mathrm{g}^{-1} \mathrm{fr}$. wt. ethanol was observed under $\mathrm{N}_{2}$. This level probably represents an equilibrium of production and release of ethanol in the tissue. In $S$. lacustris ethanol levels rose to roughly $20 \mu \mathrm{M} \mathrm{g}^{-1}$ fr. wt., within $2 \mathrm{~d}$ of $\mathrm{N}_{2}$, and no further accumulation was recorded. In $T$. latifolia there was an accumulation of ethanol to $10 \mu \mathrm{M} \mathrm{g}^{-1}$ fr. wt., which figure was not exceeded and in fact fell, showing a correlation with the decreased $A D H$ activity during the treatment. The rhizomes of these species possessed internal air spaces accounting for $25-60 \%$ of the volume of the organ (Studer, personal communication). The volume of the internal air space in Iris is not known. Only in S. lacustris rhizomes was there a cork layer to the epidermis and here lenticels were also present.

The plateaux reached for ethanol accumulation in the wetland plants (Fig. 3) were not found in the dryland species $I$. germanica. This species exhibited a steady increase in ethanol concentration in the rhizome during the whole course of the anaerobic treatment where the relatively high concentration of $71 \mu \mathrm{M} \mathrm{g}^{-1} \mathrm{fr}$. wt. was achieved. In the related I. pseudacorus the more modest figure $26 \mu \mathrm{M} \mathrm{g}^{-1} \mathrm{fr}$. wt. was accumulated. The accumulation of high concentrations which takes place in $I$. germanica may be at least partially responsible for the intolerance of longer periods of anoxia (Hetherington, Hunter and Crawford, 1983). Ability to eliminate ethanol may be greater in I. pseudacorus.

Rhizomes of all species were shown to contain adequate amounts of carbohydrates to survive $15 \mathrm{~d}$ anoxia (Fig. 4). In all species amounts of reducing sugars present during the aerobic and anaerobic treatment did not differ significantly. Levels varied between different species. When concentrations of sucrose were determined in rhizomes from aerobic and anaerobic treatments, no significant differences were found, with one exception. In Acorus calamus a slight accumulation of sucrose was found during anaerobiosis. It was, therefore, concluded that all species possessed a sufficient supply of substrate for the dissimilatory processes in the rhizomes.

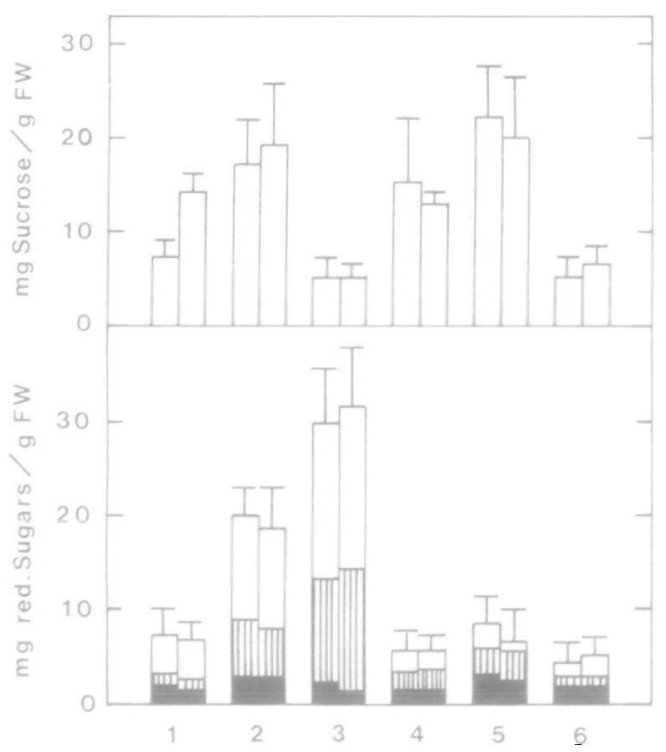

FIG. 4. Concentrations of various sugars in the rhizome after $16 \mathrm{~d}$ in air and $15 \mathrm{~d}$ in $\mathrm{N}_{2}$. Blank column $=$ total reducing sugars, shaded area $=$ glucose and lined area $=$ fructose. Mean values of $6-12$ rhizomes \pm s.d. $1=A$. calamus, $2=I$. germanica, $3=I$. pseudacorus, $4=P$. australls, $5=S$. lacustris and $6=T$. Latifolla. 
These results tend to support the initial hypothesis of this paper that the perennating organs of wetland species are able to avoid accumulation of ethanol. The plateau that is observed within the first week of anoxia in the tolerant species suggests that ethanol loss equals ethanol production and this steady state is a feature of those plant tissues that are able to survive prolonged anoxia. Further research is necessary to establish the levels of ethanol that may prove toxic to flood-sensitive species such as $I$. germanica. The toxicity of ethanol to plant tissues has been questioned in a detailed review of this subject by Jackson, Herman and Goodenough (1982). However, in these studies the conclusions were based either on the effects of ethanol given under aerobic conditions or else to seedlings where even though the root medium was anaerobic there was ready access to oxygen by diffusion from the shoot. Plant tissues are very active in their capacity to oxidize ethanol anaerobically if oxygen is available (Cossins, 1978). No examination has been made of the toxicity of ethanol when it is produced under anoxia where reducing conditions will prevent oxidative detoxification. Further work is necessary on the interactive effects of anoxia and ethanol on plant tissues, before any definite statements can be made about ethanol toxicity. The present experiments, however, do indicate that if accumulating ethanol is toxic to higher plant tissues under anaerobic conditions, then the wetland species are well adapted to maintain steady state ethanol concentrations at a low level to minimize this danger.

\section{ACKNOWLEDGEMENTS}

This research was carried out at the Institute of Plant Physiology, University of Berne, Switzerland and was supported by a Queen Elizabeth II Silver Jubilee Foundation Scholarship from the British Council which L.S.M. gratefully acknowledges.

\section{LITERATURE CITED}

ARmStrong, W., 1979. Aeration in higher plants. Advances in Botanical Research, 7, 225-332.

Bergmeyer, H. U., 1963. Methods of enzymatic analysis. Academic Press, London.

Bertani, A., Brambilla, I., and Menegus, G., 1980. Effects of anaerobiosis on rice seedlings: growth, metabolic rate and fate of fermentation products. Journal of Experimental Botany, 31, $325-31$.

Brown, A. D., Marshall, D. R., and Munday, J., 1976. Adaptedness of variants at an alcohol dehydrogenase locus in Bromus mollis L. (Soft Bromegrass). Australian Journal of Biological Sciences, 29, 389-96.

Cossins, E. A., 1978. Ethanol metabolism in plants. In Plant life in anaerobic environments. Eds D. D. Hook and R. M. M. Crawford. Ann Arbor, Michigan. Pp. 169-202.

CRAWFORD, R. M. M., 1967. Alcohol dehydrogenase activity in relation to flooding tolerance in roots. Journal of Experimental Botany, 18, 458-64.

- 1982. The anaerobic retreat as a survival strategy for aerobic plants and animals. Transactions of the Botanical Society of Edinburgh, 44, 57-63.

Davies, D. D., Grego, S., and Kenworthy, P., 1974. The control of production of lactate and ethanol by higher plants. Planta, 118, 297-310.

Duss, F., and BRÄNDLE, R., 1982. Die Ueberflutungstoleranz der Teichbinse (Schoenoplectus lacustris (L.) Palla): Die Bildung von verschiedenen Gärungsprodukten und Transportsubstanzen im Rhizomgewebe bei Sauerstoffmangel. Flora, 172, 217-22.

Francis, C. M., DevitT, A. C., and STEele, P., 1974. Influence of flooding on the alcohol dehydrogenase activity of roots of Trifolium subterraneum L. Australian Journal of Plant Physiology, 1, 9-13.

Haldemann, C., and Brändle, R., 1983. Avoidance of $\mathrm{O}_{2}$ deficit stress and release of $\mathrm{O}_{2}$ by stalked rhizomes of Schoenoplectus lacustris (L) Palla. Physiologie Végétale, 21, 109-13.

Hetherington, A. M., Hunter, M. I. S., and Crawford, R. M. M., 1983. Survival of Iris species under anoxic conditions. Annals of Botany, 51, 131-3.

Hunter, M. I. S., Hetherington, A. M., and Crawford, R. M. M., 1983. Lipid peroxidation-a factor in anoxia intolerance in Iris species. Phytochemistry, 22, 1145-7. 
Jackson, M. B., Herman, B., and Goodenough, A., 1982. An examination of the importance of ethanol in causing injury to flooded plants. Plant, Cell and Environment, 5, 163-72.

Marshall, D. R., BrouÉ, P., and Pryor, A. J., 1973. Adaptive significance of alcohol dehydrogenase isoenzymes in maize. Nature, New Biology, 244, 16-17.

MONK, L. S., and BRÄNDLE, R., 1982. Adaptation of respiration and fermentation to changing levels of $\mathrm{O}_{2}$ in rhizomes of Schoenoplectus lacustris (L.) Palla and its significance to flooding tolerance. Zeitschrift für Pflanzenphysiologie, 105, 369-74.

PradeT, A., and Bomsel, J. L., 1978. Energy metabolism in plants under hypoxia and anoxia. In Plant life in anaerobic environments. Eds D. D. Hook and R. M. M. Crawford. Ann Arbor, Michigan. Pp. 89-118.

Rumpho, M. E., and KenNedy, R. A., 1981. Anaerobic metabolism in germinating seeds of Echinochloa crus-galli (Barnyard grass). Plant Physiology, 68, 165-8.

Smith, A. M., and AP ReEs, T., 1979. Pathways of fermentation in the roots of marsh plants. Planta, $146,327-34$.

Somogyi, M., 1952. Notes on sugar determination. Journal of Biological Chemistry, 195, 19-23.

SteinmanN, F. A., and BrändLE, R., 1981. Die Ueberflutungstoleranz der Teichbinse (Schoenoplectus lacustris (L.) Palla): III. Beziehuhungen zwischen der Sauerstoffversorgung und der 'Adenylate Energy Charge' der Rhizome in Abhängigkeit von der Sauerstoffkonzentration in der Umgebung. Flora, 171, 307-14.

Torres, A. M., and DiedenhofEn, U., 1981. Sunflower alcohol dehydrogenase genotypes: germination rates and response to flooding. Environmental and Experimental Botany, 21, 35-44.

Vartapetian, B. B., Andreeva, I. N., Kozlova, G. I., and Agapova, A. A., 1977. Mitochondrial ultrastructure in roots of mesophyte and hydrophyte at anoxia and after glucose feeding. Protoplasma, 91, 243-56.

Wignarajah, K., and Greenway, H., 1976. Effect of anaerobiosis on activities of alcohol dehydrogenase and pyruvate decarboxylase in roots of Zea mays. New Phytologist, 77, 575-84. 